\title{
Clay diagenesis and low-grade metamorphism of Tithonian and Berriasian sediments in the Cameros Basin (Spain)
}

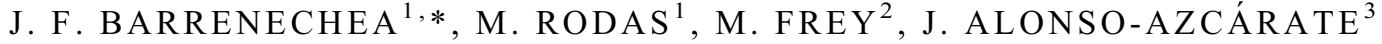 \\ AND J. R. MAS \\ ${ }^{1}$ Departamento de Cristalografia y Mineralogía, Universidad Complutense de Madrid, 28040 Madrid, Spain, ${ }^{2}$ \\ Mineralogisch-Petrographisches Institut, Basel University, CH 4056 Basel, Switzerland (deceased), ${ }^{3}$ Facultad de \\ Ciencias del Medio Ambiente, Universidad de Castilla-La Mancha, Fábrica de Armas, 45071 Toledo, Spain, and ${ }^{4}$ \\ Departamento de Estratigrafia, Universidad Complutense de Madrid, 28040 Madrid, Spain
}

(Received 29 February 2000; revised 13 October 2000)

\begin{abstract}
The clay mineral assemblages of the Tithonian and Berriasian sediments (Tera and Oncala Groups) in the eastern part of the Cameros basin are investigated at seven localities. The lowest-grade assemblage, located on the southern border of the basin, contains calcite + quartz + hematite + kaolinite + mixed-layer illite-smectite $(\mathrm{R}=1,65-85 \%$ illite layers $) \pm$ discrete illite (IC $\left.=0.5-0.65 \Delta^{\circ} 2 \theta\right)$. Systematic increases in the illite and chlorite crystallinities suggest increasing metamorphic grade from the northwest part of the basin to the southeast. This trend does not follow the pattern previously described for the overlying late Berriasian-early Aptian sediments (Urbión and Enciso Groups), which exhibit a higher metamorphic grade. This may result from local variations in sedimentary facies, as well as the circulation of hot migratory fluids. Tertiary compression occurring long after the main metamorphic event is considered to be responsible for the enhanced illite and chlorite crystallinities measured in the SE extreme of the basin.
\end{abstract}

KEYwORDS: diagenesis, low-grade metamorphism, clay minerals, illite crystallinity, chlorite crystallinity.

The pattern of low-grade metamorphism displayed by the sediments in the eastern part of the Cameros basin is important in understanding the evolution of the basin. Guiraud \& Seguret (1985) defined two isometamorphic zones, roughly concentric, and estimated maximum temperature and pressure ranges of $420-520^{\circ} \mathrm{C}$ and $0.5-4 \mathrm{kbar}$, respectively. They considered the metamorphism to be dynamothermal and contemporaneous with the sedimentary filling of the basin.

Casquet et al. (1992), Barrenechea et al. (1995) and Alonso-Azcárate et al. (1995) estimated maximum temperature and pressure of $\sim 340^{\circ} \mathrm{C}$ and 1-1.5 kbar. Alonso-Azcárate et al. (1999)

* E-mail: barrene@eucmax.sim.ucm.es calculated a temperature of $376^{\circ} \mathrm{C}$ for the metamorphism. These authors suggested that the circulation of hot migratory fluids was important in the development of the metamorphism of the Cameros Basin. This hypothesis is based on: (1) the age of the main thermal event (Middle to Upper Cretaceous), which post-dates the sedimentary filling of the basin; (2) the close relationship between the permeability and porosity of the rocks, and the pattern of mineral assemblages and illite and chlorite crystallinity; (3) the abnormally high geothermal gradient; (4) the presence of huge concentrations of large pyrite crystals with inclusions of chloritoid crystals in the Barremian Depositional Sequence at the NE sector of the basin (Alonso-Azcárate et al., 1999); and (5) the variation in the composition of fluid inclusions between different units within a given area 
(Mantilla Figueroa et al., 1998). Mata et al. (1996) related the low-grade metamorphic event to the crustal thinning associated with the extensional regime that occurred during the development of the basin.

Most of the studies performed thus far concerning the distribution of mineral assemblages and metamorphic conditions (Barrenechea et al., 1995; Alonso-Azcárate et al., 1995; Mata, 1997) focused on the so called Urbión and Enciso Groups defined by Tischer (1965) and Beuther (1965). However, no specific work has been done on the mineralogical composition of the underlying Tera and Oncala Groups. Using fluid-inclusion data from quartz-calcite veins from the Oncala Group, Mantilla Figueroa et al. (1998) concluded that the regional temperatures were probably lower than in the overlying Urbión Group, and that the composition of the fluids was different in both realms.

The aim of this paper is to present the first data on the distribution of mineral assemblages and crystal-chemical parameters of the phyllosilicates in the Tera and Oncala Groups from a series of stratigraphic profiles along the eastern sector of the basin. Special attention is paid to illite and chlorite crystallinity data, in order to estimate the degree of diagenesis or low-grade metamorphism in each area. Finally, the results are compared with the distribution obtained by previous studies for the overlying Urbión and Enciso Groups.

\section{GEOLOGICAL SETTING}

Figure 1 shows that the stratigraphic profiles studied are distributed along a NW-SE transect through the eastern sector of the Cameros basin, close to the border between the provinces of Soria and La Rioja.

The Cameros basin was developed under an extensional regime during the latest Jurassic-early Cretaceous. Its fill constitutes $>5000 \mathrm{~m}$ of sediments deposited between the Tithonian and the Early Albian. Most of the sediments are continental (fluvial and lacustrine) with minor marine inter-

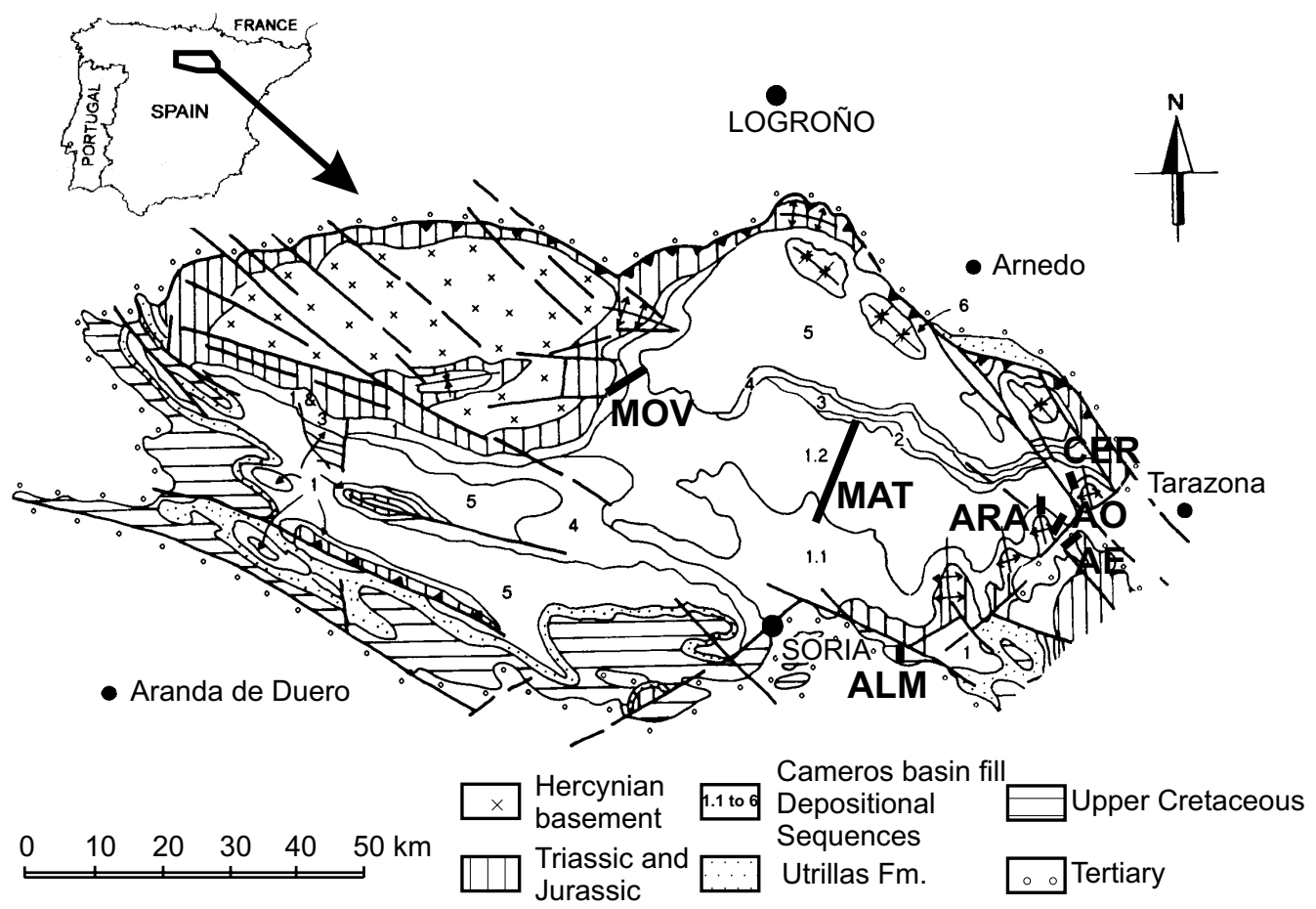

FIG. 1. Geological map of the study area, showing the location of the stratigraphic profiles: Matasejún (MAT), Montenegro-Villoslada (MOV), Almajano (ALM), Aguilar del Río Alhama (ARA), east Agreda (AE), west Agreda (AO) and Cervera del Río Alhama (CER). Modified after Guimerá et al. (1995). 
calations. During the Palaeogene and early Miocene, the basin was inverted by thrust with a displacement of $\sim 30 \mathrm{~km}$ over the Tertiary Ebro basin in the north, and a system of thrusts over the Almazán basin at the southern margin.

According to Mas et al. (1993) the sedimentary record constitutes a large megasequence bounded by two main unconformities at the base and the top (Tithonian-early Albian), and can be further subdivided into six depositional sequences (DS1 to DS6 in Fig. 1) separated by minor unconformities. The substratum consists of marine Jurassic (generally Malm) and very occasionally Triassic sediments.

The Tera and Oncala Groups correspond to the Tithonian-Berriasian depositional sequence (DS1), whereas the Urbión and Enciso Groups comprise the late Berriasian to early Aptian depositional sequences (DS2 to DS5). The unconformable contact between the Oncala and the Urbión Groups is represented everywhere by a thick bed of black shales.

\section{Sedimentological framework and samples}

A brief description of the stratigraphic profiles studied (simplified from Gómez Fernández, 1992) is given below, starting from the northwestern to the southeastern border of the basin.

The Montenegro-Villoslada profile (MOV) comprises medium-grained sandstones, with scarce, thin conglomerate layers, interbedded with red, grey and green mudstones. These sediments were considered by Gómez Fernández (1992) as representative of a meandering fluvial system. Towards the top of the profile, the amount of marls and limestones present increases gradually, together with massive, black, marly layers.

The Almajano profile (ALM) is apparently out of the NW-SE band roughly drawn by the rest of the profiles. These sediments belong to the Tera Group and represent the beginning of the filling of the basin at the southern border, since they unconformably overlay the oolitic grainstone of the 'Torrecilla en Cameros Formation' (Kimmeridgian). The profile is characterized by red mudstones displaying frequent calcretes, interbedded with layers of calcareous conglomerates which show cross-stratification. It was interpreted by Gómez Fernández (1992) as the proximal part of an alluvial system.

The sediments of the Matasejún profile (MAT) belong almost entirely to the Oncala Group, and are characterized by an alternation of lacustrine marls and limestones with green to grey mudstones and quartzites (interpreted as flood-plain deposits in a meandering fluvial system). A progressive increase in the proportion of marls and limestones with some mudrocks is observed at the top of the profile, where we find grey laminated limestones rich in ostracods and bivalves.

Finally, a set of samples collected in different stratigraphic profiles from the south-eastern extreme of the basin were grouped under the denomination SE sector. The East-Agreda (AE), West-Agreda (AO), and Aguilar del Río Alhama (ARA) profiles correspond to the Tera Group, whereas the Cervera del Río Alhama (CER) section includes sediments from the Tera and Oncala Groups. The profiles are characterized by alternating limestones, marls and calcareous breccias, with scarce mudstones and sandstones.

\section{METHODS}

$100 \mathrm{~g}$ samples were ground in a tungsten-carbide swing-mill for $20 \mathrm{~s}$. Carbonate was removed with $5 \%$ acetic acid. The $<2 \mu \mathrm{m}$ fraction was separated using differential tubes and millipore filters. Following Ca-saturation, air-dried oriented aggregates $(<2 \mu \mathrm{m})$ were prepared by pipetting suspensions $\left(\sim 5 \mathrm{mg} / \mathrm{cm}^{2}\right)$ onto glass slides. These were solvated with ethylene glycol and in some cases were heated to $550^{\circ} \mathrm{C}$ for $1 \mathrm{~h}$.

$\mathrm{X}$-ray diffraction patterns of non-oriented powders and oriented clay aggregates were collected in a Siemens D5000 diffractometer, equipped with a graphite monochromator, using $\mathrm{Cu}-K \alpha$ radiation and the Siemens SOCABIM Diffract AT3.2 Software.

The full width at half maximum (FWHM) of the (001) peak of illite and the (002) peak of chlorite (IC and $\mathrm{ChC}$, respectively) were determined. In some cases the IC values were estimated after using a deconvolution routine to overcome the overlapping with illite-smectite mixed layers. Following calibration with standards provided by B. Kübler, the anchizone boundaries for the IC values are defined at indices of 0.42 and $0.25 \Delta^{\circ} 2 \theta$. The anchizone boundaries for the $\mathrm{ChC}$ values $\left(0.21\right.$ and $\left.0.28 \Delta^{\circ} 2 \theta\right)$ are taken from a correlation performed by AlonsoAzcárate et al. (1995) using samples from different areas within the Iberian Chain.

White mica polytype determinations were performed following the method proposed by Callière et al. (1982). 


\section{RESULTS}

In the northwestern border of the basin (MOV profile), all of the 38 samples analysed contain quartz, illite and chlorite. Calcite is present in variable proportions in samples from the base and the top of the profile, whereas trace amounts of albite were recognized in the middle part. Hematite appears in seven red mudrocks from the initial part of the sequence. In two massive black marly layers from the top of the profile, gypsum and dolomite were detected, together with quartz, calcite, illite and chlorite. Only the first and the last samples collected along the profile contain paragonite. The $10 \AA$ illite peak in these samples invariably shows a tail on the low-angle side which disappears after ethylene-glycol solvation, revealing the presence of a variable proportion of expandable layers associated with illite.

The 16 samples from the Tera Group collected at the southern border of the basin (ALM profile) contain calcite, quartz, hematite (except for sample ALM-05), kaolinite and an ordered mixed-layer illite-smectite (with $\mathrm{R}=1$ and $65-85 \%$ illite layers). Discrete illite was also detected in three samples. The characterization of the mixed-layer illite-smectite was performed using the criteria proposed by Moore \& Reynolds (1998). The airdried samples display intense peaks at 27.95, 11.92 and $4.96 \AA$, and following glycolation they are shifted to $28.8,12.8,9.22,5.26$ and $4.48 \AA$ (Fig. 2). The method uses the difference in the relative positions of the $001 / 002$ and $002 / 003$ reflections at 9.22 and $5.26 \AA$ respectively.

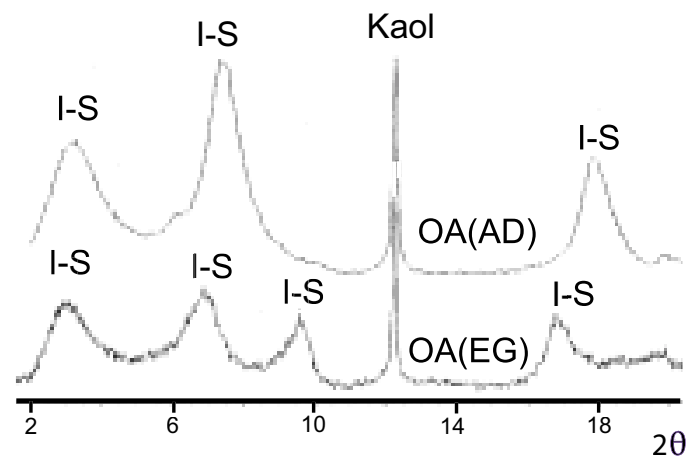

FIG. 2. XRD traces of air-dried, OA(AD), and ethyleneglycol solvated, OA(EG), clay separates of sample ALM05, containing kaolinite (Kaol) and regular interstratification between illite and smectite (I-S).
Thirty eight samples studied in the depocentral sector (MAT profile) contain quartz and white K-mica \pm calcite \pm dolomite \pm albite \pm chlorite \pm corrensite \pm paragonite $\pm \mathrm{Na}, \mathrm{K}$-mica. Calcite is present in relatively large proportions in most samples from the initial and final parts of the profile, its presence being restricted to a small number of samples in the middle of the profile. Dolomite was recognized in five samples from the top and one from the base of the sequence, always together with quartz and calcite. An interesting feature observed for most samples containing dolomite was the lack of chlorite and/or corrensite (or a significant decrease in its proportion). Small amounts of albite were also detected along the profile, except for three samples, which in turn contain paragonite and $\mathrm{Na}, \mathrm{K}-$ mica. A detailed description of the clay mineral assemblages of this profile can be found in Barrenechea et al. (2000).

Most of the 32 samples analysed in the CER, AO and $\mathrm{AE}$ profiles (SE extremity of the basin) contained quartz, calcite, illite and showed variable proportions of chlorite, paragonite and $\mathrm{Na}, \mathrm{K}-$ mica. The mineral assemblage of 13 samples from the ARA profile was different, since they consist of illite \pm chlorite \pm dolomite \pm calcite \pm quartz. In this case, no exclusive relationship was detected between dolomite and chlorite.

\section{Illite and chlorite crystallinity data}

The illite and chlorite crystallinity data (IC and $\mathrm{ChC}$ respectively) for the air-dried samples are presented in Fig. 3. The lowest crystallinities were measured in samples from the ALM profile, from the southern border of the basin. The IC values in this particular case where estimated after using a deconvolution routine to overcome the overlapping with illite-smectite mixed layers. They range between 0.50 and $0.62 \Delta^{\circ} 2 \theta$, clearly within the diagenetic realm.

The IC data for samples from the Montenegro profile, from the northwestern border of the basin, show values between 0.31 and $0.58 \Delta^{\circ} 2 \theta$, with a mean of $0.40 \Delta^{\circ} 2 \theta$. Most of the illite crystallinity measurements indicate that these samples were subjected to low-anchizonal conditions, although a few of them fall within the field of diagenesis. This apparent scatter is at least partly attributable to different lithologies. Figure 4 shows that mudstones tend to display slightly better illite crystallinities 

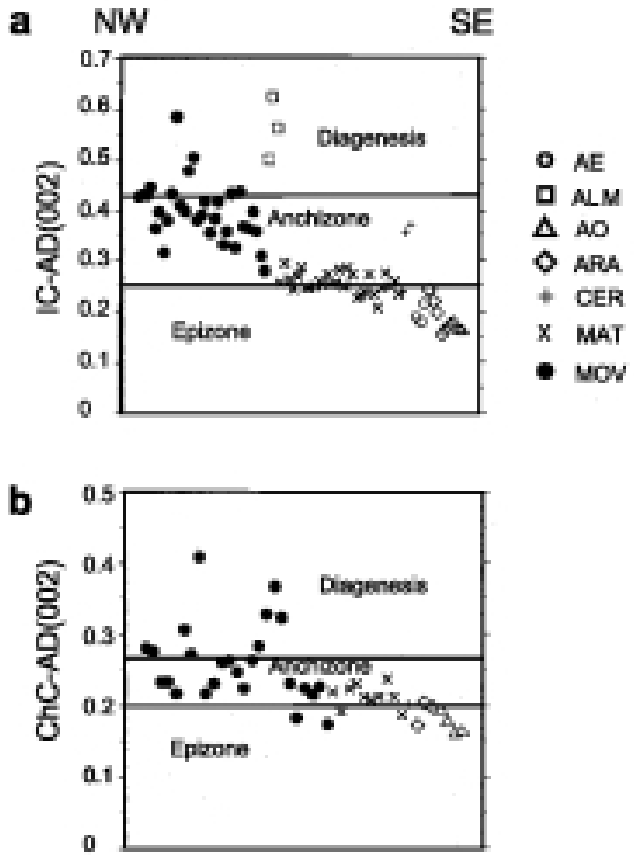

FIG. 3. Variation of illite (IC-AD(002)) and chlorite $(\mathrm{ChC}-\mathrm{AD}(002))$ crystallinity data for the different profiles from the northwestern to the southeastern border of the basin.

than the intercalated marly samples, while the $\mathrm{ChC}$ values are similar in both lithologies.

Samples from the MAT profile correspond to the limit between anchi and epimetamorphic conditions, with a mean IC value of $0.25 \Delta^{\circ} 2 \theta$. The highest crystallinities are found in the SE sector, where most of the data plot within the epimetamorphic realm. However, the IC and $\mathrm{ChC}$ data determined in

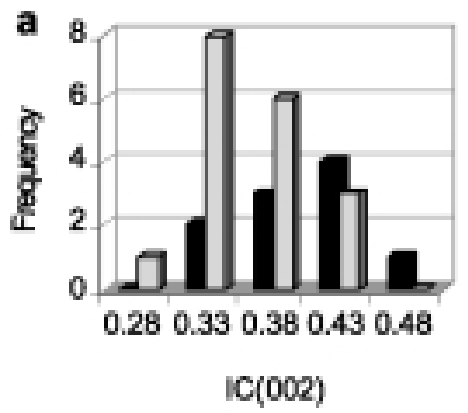

samples from the CER profile correspond to the anchizone. No significant differences are observed in these profiles between IC values measured in marls and mudstones.

There is a slight narrowing $(\sim 10-15 \%)$ of the $10 \AA$ peak after glycolation, suggesting the presence of a small proportion of expandable layers associated with illite (Fig. 5a). There is a reasonably good correlation between the $\mathrm{IC}(002)$ and $\mathrm{IC}(004)$ values (Fig. 5b). In samples from the MAT profile, the lack of a linear correlation is probably related to the overlapping between the (004) illite peak at $5 \AA$ and the (006) corrensite peak at $\sim 4.86 \AA$. No uniform vertical variation was detected in the IC data along the profiles.

Polytype determinations show that illite from the epimetamorphic samples consists predominantly of the $2 M_{1}$ polytype, although in some samples from the MAT profile, up to $25 \%$ of the $1 M$ polytype was detected. The proportion of $2 M_{1}$ polytype in the illite decreases in the NW sector (MOV profile) and at the southern border (ALM profile) of the basin (Fig. 6).

For any given sample, the $\mathrm{ChC}$ values are consistently narrower than the IC ones (Fig. 7), but they seem to corroborate the estimations based on IC measurements, with a progressive increase in the metamorphic conditions from the NW border to the SE sector of the basin (Fig. 3b).

\section{DISCUSSION}

The combination of clay mineral assemblages and crystallinity data allows us to establish the distribution of diagenetic to low-grade metamorphic conditions among the studied profiles of the Tithonian-Berriasian depositional sequence. These

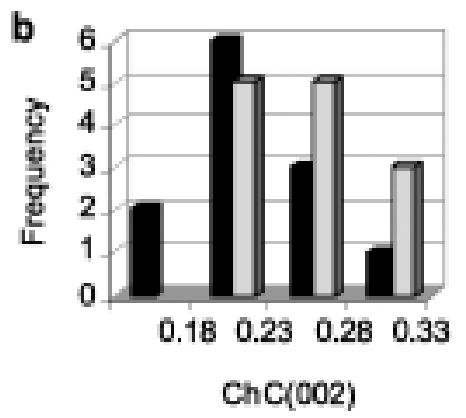

FIG. 4. Plot of (a) IC(002) and (b) ChC(002) data measured in marls (black bars) and mudstones (grey bars) from the MOV profile. 

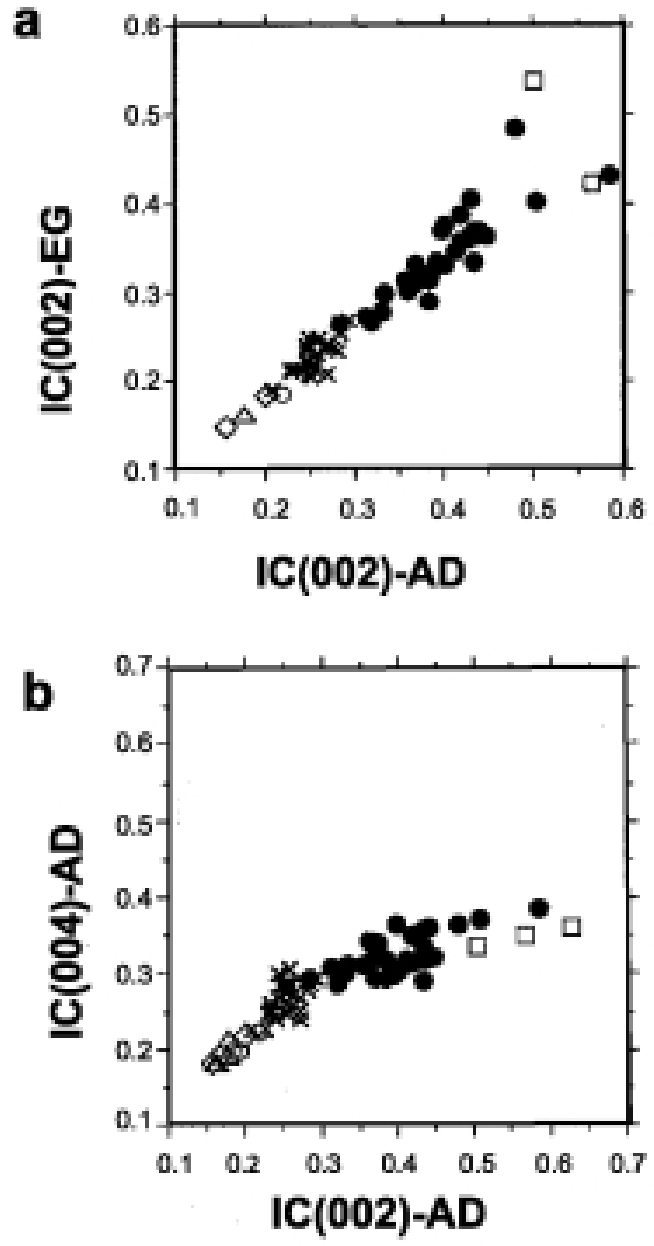

FIG. 5. (a) Plot of illite crystallinity data measured in air-dried (IC(002)-AD) and ethylene-glycol solvated (IC(002)-EG) oriented aggregates for all of the samples analysed. (b) Plot of the full-width at halfheight for the illite 002 and 004 reflections (IC(002)$\mathrm{AD}$ and $\mathrm{IC}(004)-\mathrm{AD}$, respectively). Legend to symbols as in Fig. 3.

results are summarized in Fig. 8. Both the Tera and Oncala Groups are discussed together, although local variations in sedimentary facies and bulk composition were evaluated carefully in the interpretation of the results.

The lowest-grade conditions correspond to the southern border of the basin (ALM profile), as evidenced by the presence of kaolinite, an ordered mixed-layer illite-smectite, the illite polytype $(1 M$ predominantly) and illite crystallinity data, which are typically diagenetic. No $\mathrm{ChC}$ data are available in this case, since there is no chlorite in these samples.

The clay mineral assemblages and crystallinity data for the rest of the profiles yield a well defined trend of increasing metamorphic conditions from the northwest to the southeastern sector of the basin. It is important to note that, despite the fact that there is poor correlation between the IC and $\mathrm{ChC}$ values, the regression equation obtained in the present study is very similar to that proposed by Alonso-Azcárate et al. (1995) (Fig. 7). Therefore, although chlorite crystallinity has proved to be a less sensitive indicator, in this case it can be used to define the transition to low-grade metamorphic conditions. This poor correlation is partly due to differences observed in the IC data from marls and mudstones in diagenetic and low-anchizonal samples, since the mudstones tend to show slightly better crystallinities. As observed by AlonsoAzcárate et al. (1995) in samples from the late Barremian-early Aptian depositional sequence, these differences become negligible in samples from high-anchizone and epizone.

In addition, the results show that the proportion of $2 M_{1}$ polytype in the illites increases gradually from diagenetic to epimetamorphic samples. The evolution from $1 M$ to $2 M_{1}$ polytype seems to be largely complete in samples from the depocentral sector (MAT profile), where the IC and ChC values are indicative of high anchizone/epizone conditions.

At the northwestern border of the Cameros basin (MOV profile), both the IC and $\mathrm{ChC}$ values, together with the presence of a variable proportion of expandable layers associated with the $10 \AA$ illite peak and of paragonite and $\mathrm{Na}, \mathrm{K}$-mica in a few samples, are indicative of the boundary between deep diagenetic and low anchizonal conditions. These results agree with previous estimates in the area for the overlying materials of the Urbión Group (Barrenechea et al., 1995).

However, the results presented here are at variance with previous assumptions on the distribution of metamorphic conditions along the depocentral and southeastern sectors of the basin. According to Barrenechea et al. (1995) and Alonso-Azcárate et al. (1995) the highest metamorphic conditions for the sediments of the overlying Berriasian to early Aptian depositional sequences (Urbión and Enciso Groups) were found in the depocentral areas, with a progressive decrease towards the $\mathrm{SE}$ and $\mathrm{NW}$ 


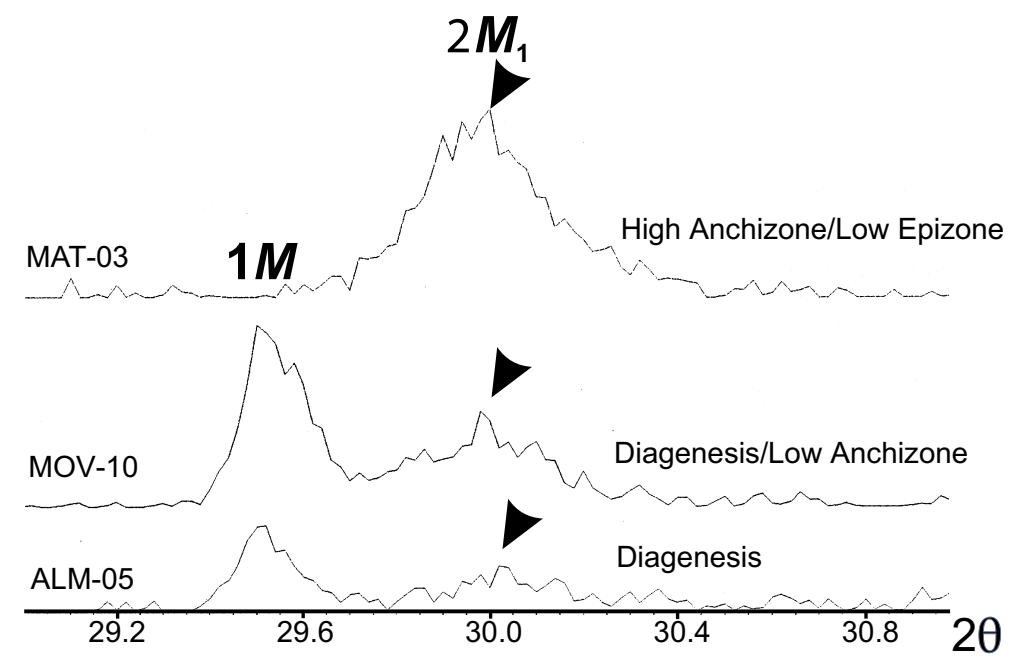

FIG. 6. XRD traces of selected samples prepared for the study of illite polytypes. The relative areas of the two peaks indicated were used to estimate the relative proportions of the $1 M$ and $2 M_{1}$ polytypes.

borders. Conversely, the highest metamorphic conditions in the present study correspond to the different profiles studied in the SE sector of the basin, where the IC and $\mathrm{ChC}$ data are characteristic of the epizone.

An interesting feature is the fact that the metamorphic conditions estimated for the sediments of the Tithonian-Berriasian depositional sequence (Tera and Oncala Groups) in the depocentral areas of the basin (MAT profile) are unexpectedly lower

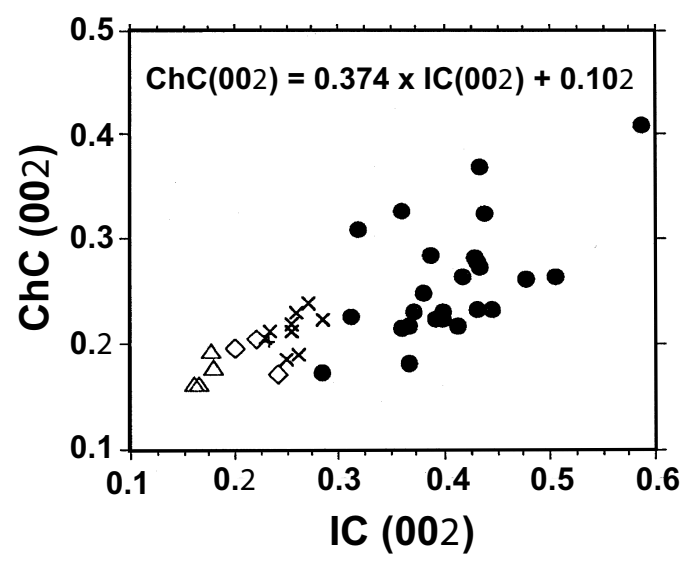

FIG. 7. Correlation between illite and chlorite crystallinity data for samples from the different stratigraphic profiles. Lengend to symbols as in Fig. 3. than those described by Barrenechea et al. (1995) for the overlying Urbión Group, where the presence of chloritoid and the $\mathrm{ChC}$ values are characteristic of the epizone. This apparent thermal inversion may reflect the importance of the circulation of hot migratory fluids and bulk composition in the development of the metamorphism of the Cameros Basin. In fact, on the basis of a detailed fluid inclusion study, Mantilla Figueroa et al. (1998) concluded that the temperature of vein-forming fluids in the Oncala Group was lower than in the overlaying Urbión Group, and that the composition of the fluids was also different in both realms. These authors suggested that the black shales from the top of the Oncala Group acted as a first order geological barrier, and were responsible for the lack of hydrological communication between the Urbión and Oncala Groups. In addition, Barrenechea et al. (2000) conclude that there is a clear control of the sedimentary facies on the distribution of mineral assemblages of the MAT profile. They suggest that the presence of corrensite in these samples might be regarded as additional evidence for the hydrothermal character of the metamorphism within the Cameros basin, since this phase is usually considered to be characteristic of diagenesis or incipient anchimetamorphism. Corrensite was formed by hydrothermal alteration occurring during a relatively short time, and the different reaction rates for the various phases present in these 


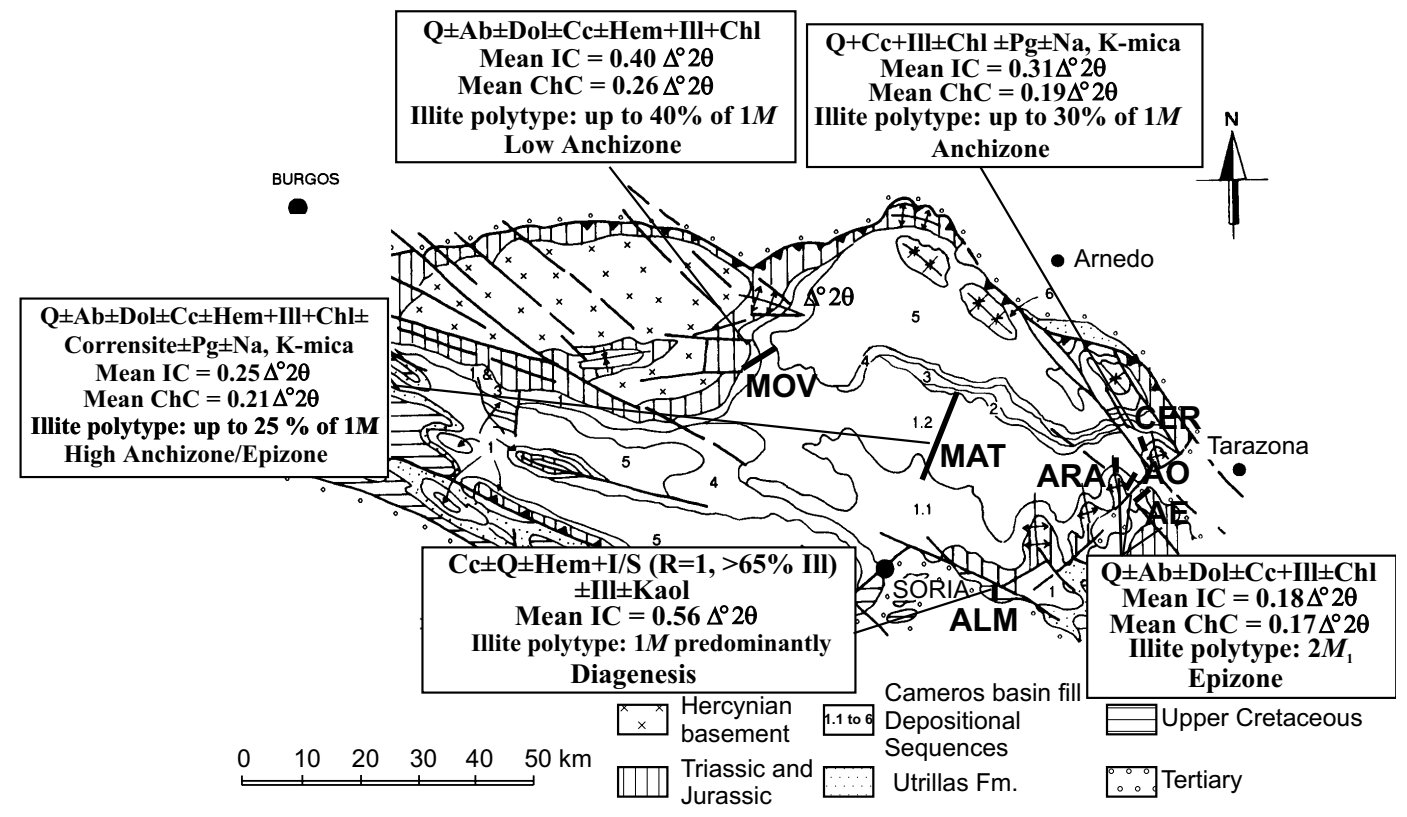

FIG. 8. Map of the study area, showing the distribution of the clay mineral associations and crystallinity data for the different stratigraphic profiles. The estimated diagenetic or low-grade metamorphic degree is indicated for each area. $\mathrm{Q}=$ quartz; $\mathrm{Ab}=$ albite; $\mathrm{Cc}=$ calcite; $\mathrm{Hem}=$ hematite; $\mathrm{Ill}=$ illite; $\mathrm{Chl}=$ chlorite; $\mathrm{Pg}=$ paragonite; Dol $=$ dolomite; I-S = mixed-layer illite-smectite.

rocks would explain the apparent misfit between mineral assemblage and crystallinity data. Barrenechea et al. (1995) and Alonso-Azcárate et al. (1995) also found a close relationship between the clay mineral variations and the changes in sedimentary facies (i.e. presence of carbonate, organic matter, permeability) for the overlying Urbión and Enciso Groups.

Finally, the highest illite and chlorite crystallinities were measured in samples from the SE sector of the basin. The enhanced values are probably related to the Tertiary compression that affected these materials long after the peak metamorphic conditions were attained in the rest of the basin. Note that the ARA, AO and AE profiles are distributed around the Pégado anticline (Fig. 1). The role of deformation strain as an important factor in the improvement of illite crystallinity was described in previous studies (Fernández-Caliani \& Galán, 1992; Wang et al., 1996; Frey \& Robinson, 1999).

The data from the present study imply that there is a clear difference in the distribution of clay mineral assemblages and crystallinity data between the Tithonian-Berriasian (Tera and Oncala Groups) and the late Berriasian-early Aptian (Urbión and Enciso Groups), with a progressive increase in the estimated metamorphic conditions from the northwestern to the southeastern sectors in the former and a gradual decrease from the depocentral area to the borders of the basin in the latter.

\section{ACKNOWLEDGMENTS}

This study was supported by the Spanish DGICYT through project PB97-0298. J.F. Barrenechea is indebted to Dr S.Th. Schmidt and Dr R. FerreiroMählmann for their suggestions and discussions at an early stage of this work. Critical reviews by C.V. Jeans, and J.M. González López helped to improve the manuscript.

\section{REFERENCES}

Alonso-Azcárate J., Barrenechea J.F., Rodas M. \& Mas J.R. (1995) Comparative study of the transition between very low grade and low grade metamorphism in siliciclastic and carbonate sediments. Early Cretaceous, Cameros Basin (North Spain). Clay 
Miner. 30, 407-419.

Alonso-Azcárate J., Rodas M., Bottrell S.H., Raiswell R., Velasco F. \& Mas J.R. (1999) Pathways and distances of fluid flow during low-grade metamorphism: Evidence from pyrite deposits of the Cameros Basin, Spain. J. Metam. Geol. 17, 339-348.

Barrenechea J.F., Rodas M. \& Mas J.R. (1995) Clay mineral variation associated with diagenesis and low grade metamorphism of Early Creataceous sediments in the Cameros Basin, Spain. Clay Miner. 30, 119-133.

Barrenechea J.F., Rodas M., Frey M., Alonso-Azcárate J. \& Mas J.R. (2000) Chlorite, corrensite, and chlorite-mica in late jurassic fluvio-lacustrine sediments of the Cameros basin of northeastern Spain. Clays Clay Miner. 48, 256-265.

Beuther A. (1965) Geologische untersuchungen in Weladen und Utrillas Schichten im Westteil der Sierra de los Cameros (Nordwestlich Iberischen Ketten). Geol. Jahrb. Biehefte, 44, 103-121.

Caillère S., Henin S. \& Rautereau M. (1982) Minèralogie des Argiles. I. Structure et Propriétés Physico-chimiques. Masson ed., Paris.

Casquet C., Galindo C., González Casado J.M., Alonso A., Mas J.R., Rodas M., García E. \& Barrenechea J.F. (1992) El metamorfismo en la Cuenca de los Cameros. Geocronología e implicaciones tectónicas. Geogaceta, 11, 22-25.

Fernández Caliani J.C. \& Galán E. (1992) Influence of tectonic factors on illite crystallinity: a case study in the Iberian pyrite Belt. Clay Miner. 27, 385-388.

Frey M. \& Robinson D. (1999) Low-grade Metamorphism (M. Frey \& D. Robinson, editors). Blackwell Science Ltd, Oxford, UK.

Gómez Fernández J.C. (1992) Análisis de la Cuenca sedimentaria de los Cameros durante sus etapas iniciales de relleno en relación con su evolución paleogeográfica. $\mathrm{PhD}$ thesis, Univ. Complutense de Madrid.
Guimerá J., Alonso A. \& Mas J.R. (1995) Inversion of an extensional-ramp basin by a neoformed thrust: The Cameros basin (N Spain). Pp. 433-453 in: Basin Inversion (J.G. Buchanan \& P.G. Buchanan, editors). Geol. Soc. Spec. Publ. 88. Geological Society, London.

Guiraud M. \& Seguret M. (1985) A realising solitary overstep model for the late Jurassic-Early Cretaceous (Wealdian) Soria strike-slip basin (Northern Spain). SEPM Spec Publ. 37, 159-175.

Mantilla Figueroa L.C., Casquet C. \& Mas J.R. (1998) Los paleofluidos en el grupo Oncala, Cuenca de Cameros (La Rioja, España): Datos de inclusiones fluidas, isótopos de oxígeno y SEM. Geogaceta, 24, $145-148$.

Mas J.R., Alonso A. \& Guimerá J. (1993) Evolución tectonosedimentaria de una cuenca extensional intraplaca: la cuenca finijurásica-eocretácica de Los Cameros (La Rioja-Soria). Rev. Soc. Geol. España, 6, 129-144.

Mata M.P. (1997) Caracterización y evolución mineralógica de la cuenca mesozoica de Cameros (SoriaLa Rioja). PhD thesis, Univ. Zaragoza, Spain.

Mata M.P., Gil Imaz A., Casas Sainz A., Pocovi J.A. \& Canals A. (1996) La extensión cretácica en la Cuenca de Cameros: resultado del análisis estructural de grietas de cuarzo y del estudio de inclusiones fluidas. Geogaceta, 20, 893-896.

Moore D.M. \& Reynolds Jr., R.C. (1998) X-ray Diffraction and the Identification and Analysis of Clay Minerals. Oxford University Press, New York.

Tischer G. (1965) Über die Wealden-Ablagerung und die Tektonik der östlichen Sierra de los Cameros in den norwestlichen Iberischen Ketten (Spanien). Geol. Jahrb. Biehefte, 44, 123-164.

Wang H., Frey M. \& Stern W. (1996) Diagenesis and metamorphism of clay minerals in the Helvetic Alps of eastern Switzerland. Clays Clay Miner. 44, $96-112$. 
